\title{
Corporate Environmental Performance and the Choice of Export Mode - Based on the Theory of Heterogeneous Firm Trade
}

Cuihong Yao ${ }^{\text {a }}$, Alisha Ismail ${ }^{\text {, }}$, Noor Azura Azmanc, a School of Economics and Management, Guangdong University of Petrochemical Technology, Maoming 525000, China, ${ }^{\mathrm{a}, \mathrm{b}, \mathrm{c}}$ Department of International Business, School of International Studies, Universiti Utara Malaysia, Sintok 06010, Malaysia

Heterogeneous firm trade theory holds that firms' productivity is closely related to firms' export mode and Corporate Environmental Performance (CEP). CEP as one of the important elements associated with firms' productivity, has a significant impact on firms' export mode. The objective of the paper is to assess the enterprises with import and export business in Maoming City. Primary data was used to obtain data, while binary logistic regression analysis was used to analyse the data to determine the influence of CEP on export mode. The results show that the CEP has a positive impact on the export mode. Furthermore, results show that enterprises with better CEP are more inclined to choose the direct export mode, and vice versa. This result is consistent with the theory of heterogeneous firm trade. The study recommends that the Chinese government should give full consideration to the export mode of enterprises when making export policies and make full use of CEP's positive influence on the export mode to promote the internationalisation strategy of enterprises and realise the maximisation of enterprise value.

Keywords: Heterogeneous, Theory, CEP, Export Mode, Hierarchy, Value 
International Journal of Innovation, Creativity and Change. www.ijicc.net

Volume 15, Issue 6, 2021

\section{INTRODUCTION}

Heterogeneous firm trade theory holds that firms' productivity is closely related to their export mode. Firms with low productivity choose the indirect export mode, while those with high productivity choose the direct export mode. Firms in between choose a mixed export mode of both indirect and direct (Zhou, Wu \& Liu, 2015). At present, the voice of environmental protection is rising day by day. As one of the important elements related to the productivity of enterprises, whether and how the Corporate Environment Performance (CEP) can affect the choice of export mode has become a new subject of theoretical research.

At present, the studies on CEP and export mode selection mainly focus on the following aspects: Firstly, the evaluation method of CEP. The evaluation methods of CEP mainly include the following: (i) to develop a standard system for CEP evaluation, such as the International Organization for Standardization (ISO) ISO14031 (ISO 1999) ; (ii) model construction for evaluation, such as data envelopment analysis (Zhu,2015; Li \& Qiu,2013), Analytic Hierarchy Process (Li,2013), Fuzzy Comprehensive Evaluation (Tian, 2011) and Ecological Efficiency Model (Xie, 2012); (iii) to use relevant data directly for alternative evaluation, such as recycling percentage of waste (Al-Tuwaijri, Christensen, \& Hughes, 2004) or Environmental Performance Index score of the US Council on Economic Priorities (Hughes, Anderson \& Golden, 2001) to measure CEP.

Secondly, influencing factors and economic consequences of CEP. Existing studies on the influencing factors of CEP mainly include government pressure (Pang \& Rao, 2019), market pressure (Shang \& Zhu, 2018; Li, 2017), stakeholders (Tan \& Wang,2019), firm characteristics (Yang, 2019; Yang \& Xie, 2019; Alat, et al., 2019), corporate governance (Hoang, Abeysekera \& Ma, 2016; Walls, Berrone \& Phan, 2012; Liao \& Yan, 2015) etc. Research on the economic consequences of CEP mainly focuses on the impact of environmental performance on financing capacity (Ye, 2015; Ma, 2014), financial performance (Hang, Geyer-Klingeberg, Rathgeber, \& Stock1,2017; Hussain, Rigoni, \& Cavezzali,2016; Hu, 2012) and the impact of productivity (Ambec, 2008). 
Thirdly, Influencing factors of enterprise export mode. These scholars have diversified studies on the influencing factors of export model, including institutional and environmental factors (Blue Hailin et al., 2010), productivity (Ahn, Khandelwal, \& Wei, 2011; Li Chunding, 2015), characteristics of management (Bo Bemhard Nielsen, Sabina Nielsen, 2011), financing ability factors (Yang \& Xu, 2015), enterprise-scale, and innovation ability factors (Ma, 2014).

From the existing literature, the existing research results still have the following shortcomings: First, there is no unified CEP evaluation system in line with China's economic development level; Second, the research on the economic consequences of CEP mainly focuses on financing capacity and productivity, while the research on the influencing factors of export mode mostly focuses on enterprise productivity and scale, and few studies directly combine CEP with export mode choice.

Based on the above analysis, this paper, based on the heterogeneity trade theory, uses the productivity transmission mechanism to link the CEP with the choice of export mode directly. The specific objectives of this research are: To understand the current situation of the environmental performance of enterprises in China; To synthesise the effects of CEP on enterprise export model; Design the overall improvement of CEP, optimise the export mode of enterprises and enhance the international competitiveness of the countermeasures and suggestions.

This study tries to make contributions in the following aspects. From theory, this paper is on the enterprise environmental performance evaluation system and the study of the economic consequences. It is the study of factors affecting the export model, a combination of both the theory of environmental accounting and heterogeneity crossover study contents of trade theory that also help to improve the heterogeneity enterprise trade theory research on the applicability of Chinese enterprises. On the one hand, it can provide a basis for the policy formulation of relevant government departments from the perspective of management. A direct export is more advanced than that of indirect exports value realisation ways. In order to optimise the export model of enterprises, improve the international competitiveness of enterprises, to better promote the development of an international strategy to provide a scientific and reasonable platform, the government is in urgent need of the related studies that provide the basis for policymaking. This study can provide data basis for the policy making of government departments. On the other hand, by analysing the positive economic consequences of CEP's improvement, this paper provides a powerful support for China's export enterprises to actively improve CEP and expand direct exports to achieve higher returns of enterprise value. 
International Journal of Innovation, Creativity and Change. www.ijicc.net

Volume 15, Issue 6, 2021

\section{THEORETICAL FRAMEWORK AND HYPOTHESES DEVELOPMENT}

So, what affects corporate productivity? Scholars believe that productivity is the result of firms' self-selection. If the productivity of an enterprise is the same at the beginning of its establishment, the enterprise can independently choose technology, labour force, capital, etc., and thus the differences in productivity levels between enterprises are generated (Jing, 2019). Similarly, firms are free to choose between environmentally friendly action or inaction and between high-quality action and low-level action, which affects their productivity. Under the concept of total factor productivity, productivity including physical factor productivity (such as capital, labour and land productivity of) and intangible factor productivity (productivity of technology innovation and management innovation) (Feng, 2016), enterprise environmental performance mainly affects intangible factor productivity:

(1) management innovation boosts productivity. Needs good CEP through the establishment of environment management skills, management systems and practices, and environmental management systems to optimise the environment of enterprise resource integration, reduce the probability of environmental accidents, thus reducing environmental compliance costs. This kind of environment management innovation allows the enterprise, in the face of environmental regulatory pressure, to form a unique competitive advantage.

On the other hand through good environmental management set up it can: develop a "green" image to improve the corporate reputation;improve employee satisfaction; improve employee satisfaction;get money at a lower cost in the capital markets;

improve customer "loyalty" as the customer attaches great importance to the case of "green mark", this kind of "loyalty" is stronger.

(2) Technological innovation improves productivity. Enterprises' investment in environmental protection will bring the innovation of new products, new technologies and new processes. On the one hand, it can reduce the amount of energy used and improve the efficiency of using other resources. On the other hand, through clean technologies, it can reduce waste management costs and achieve energy conservation and emission reduction. CEP performance impacts enterprise productivity through the "dual-core" mode of management innovation and technological innovation. 
International Journal of Innovation, Creativity and Change. www.ijicc.net

Volume 15, Issue 6, 2021

Based on the above analysis, it can be seen that there is a causal logic relationship between CEP and export mode, and enterprise environmental management innovation and environmental technology innovation affecting enterprise productivity, which effects enterprise's choice of export mode. According to the Heterogeneous Firm Trade Theory, firm productivity is the key factor that determines the choice of export mode. If the firm's productivity is low, it can enter the international market through trade intermediaries; if productivity is high, it can choose to export directly to realise its value better. Accordingly, the hypotheses proposed in this paper are as follows:

$\mathrm{H}_{1}$ : Enterprises with higher CEP are more inclined to choose direct export mode; On the contrary, enterprises with lower CEP are more inclined to choose the indirect export mode.

\section{METHODS}

\subsection{Variable Measurement and Definition}

\subsubsection{Enterprise Export Mode}

This paper assesses the export enterprises in Maoming City as the object of investigation and analysis. According to the investigation, there are only two direct export and indirect export cases, and the number of mixed exports is minimal and unrepresentative. Therefore, this paper adopts two export modes, namely direct export and indirect export. We set a dichotomy dummy variable $\mathrm{EM}$, where $\mathrm{EM}=0$ indicates an indirect exit and $\mathrm{EM}=1$ indicates a direct exit.

\subsubsection{CEP}

The disclosure of corporate environmental information, especially the disclosure of quantitative data, is seriously lacking in China, so it isn't easy to select proxy variables for corporate environmental performance. The variables selected by scholars are not uniform, which can be mainly divided into three categories: (i) single variable. For example, the discharge fee of unit operating income (Yang, 2019; Hu, 2012) and environmental strategy (Tang, 2019) as proxy variables of CEP; (ii) use multivariate as substitute variable. For example, the CEP is represented by whether it has been punished for excessive emissions and the type of punishment (NYU, 2011); whether it has passed the ISO140001 certification and received environmental punishment is taken as proxy variables (Wang, 2012); the environmental 
protection level of the enterprise's products and the reputation of the society for the products are taken as proxy variables (Cheng, 2012). (iii) the comprehensive scoring results were used as proxy variables. For example, the environmental performance index is constructed from resource and material consumption, pollutant control and treatment, and environmental protection investment to comprehensively reflect the environmental performance level of enterprises (Chen \& Chun, 2013).

The third point of view is adopted in this paper. Firstly, the index system of enterprise environmental performance evaluation is constructed from three aspects: enterprise environmental management innovation performance, enterprise environmental technology innovation performance and energy conservation and emission reduction performance.Then, weighting and scoring were given to each index, and the comprehensive scoring results were calculated.Finally, the comprehensive scoring results are used as proxy variables of corporate environmental performance.

The construction of specific enterprise environmental performance indicators is as follows:

(1) Environmental technology innovation indicators. For the whole enterprise, environmental investment is all the input index of its environmental performance, but it is directly related to enterprise environmental technology and environmental management innovation. In the environmental protection investment, investment in research and development is taken as the investment in environmental protection technology. The ratio of environmental protection technology investment to operating income is taken as the investment index of environmental protection technology innovation performance. The ratio of other environmental protection investment, excluding environmental protection technology investment to operating income is taken as the investment index of environmental management innovation performance. The direct output index of environmental technology innovation performance is reflected by environmental technology innovation achievements and environmental product research and development.

(2) Environmental management innovation indicators. The output indicators of environmental management innovation performance are mainly establishing the environmental management system, the training of environmental protection personnel and the construction of green industrial chain, etc. The negative output of environmental violation is the negative output. 
(3) The spill over efficiency of environmental technology and management innovation. Environmental technology and environmental management activities on enterprises' production process, which will bring benefits of energy conservation and emission reduction. Therefore, the comprehensive utilisation rate of "three wastes", the operation rate of environmental protection equipment and the implementation of cleaner production is taken as the input indicators of energy conservation and emission reduction of enterprises. In terms of output indicators, the performance of energy conservation and emission reduction is mainly the reduction of energy consumption and resource usage and the reduction of "three wastes" emissions, including comprehensive energy consumption per ten thousand yuan of output value and "three wastes" emissions per ten thousand yuan of output value.

(4) The weighting of each index. The weighting methods include subjective weighting methods (such as analytic hierarchy process) and objective weighting methods (factor analysis method). Due to the short time of enterprise environmental performance implementation and lack of historical data, it is difficult to adopt an objective weighting method. The index system related to environmental performance is complex. Therefore, this paper adopts the analytic hierarchy process to weighting environmental performance indicators. The relative weight and final ranking value of each index calculated by the analytic hierarchy process software (YAHP version 0.6.0) are shown in Table 1 for their meanings and weights.

In accordance with relevant national laws and regulations, ISO14031 standard and relevant industry regulations, the CEP indicators are divided into four levels. We invited 16 experts, 7 professional teachers in colleges and universities and 9 senior managers in enterprises, to score according to the collected data combined with the scoring level. Finally, the specific score of each index was obtained by an arithmetic average score of each expert.

According to the specific score and weight of each index, the score of CEP can be calculated by the formula as follows:

$$
\mathrm{CEP}_{\mathrm{i}}=\sum \mathrm{W}_{\mathrm{i}} \mathrm{P}_{\mathrm{i}}
$$

Where $\mathrm{W}_{\mathrm{i}}$ represents the weight of the ith index, and $\mathrm{P}_{\mathrm{i}}$ represents the score of the ith index. The CEP score can be calculated from formula 1. 
International Journal of Innovation, Creativity and Change. www.ijicc.net

Volume 15, Issue 6, 2021

\subsection{Model}

According to the characteristics of variables, the export model of explained variables is measured by classification indicators. If the enterprise environmental performance is directly measured by scores, it is a continuous variable. Binary Logistic regression model is adopted. The model is constructed as follows:

$$
\operatorname{Logit}\left[\mathrm{p}\left(\mathrm{EM}_{\mathrm{i}}=\mathrm{k}\right)\right]=\ln \left[\mathrm{p}\left(\mathrm{EM}_{\mathrm{i}}=\mathrm{k}\right) / 1-\mathrm{p}\left(\mathrm{EM}_{\mathrm{i}}=\mathrm{k}\right)\right]=\alpha+\beta_{1} \times \mathrm{CEP}_{\mathrm{i}}+\beta_{2} \text { Control }
$$

Where k represents the export mode, with a value of $0,1 . \mathrm{CEP}_{i}$ represents the score of enterprise environmental performance, and Control represents the Control variable.

At the same time, in order to further verify the results of Equation (2) and to understand the more detailed impact of CEP on export mode, we divide the scores of CEP into four different groups to test the impact of CEP on export mode under different groups. We use $\mathrm{CEP}_{0}, \mathrm{CEP}_{1}$, $\mathrm{CEP}_{2}$ and $\mathrm{CEP}_{3}$ respectively CEP for "failed", "pass", "good" and "excellent". The grouping of the four groups of standard for CEP score less than 60 points, is greater than or equal to 60 points less than 70 points, is greater than or equal to 70 points is less than 80 points, and is greater than or equal to 80 , the assignment of $0,1,2$ and 3 .

The model we built is as follows:

$$
\begin{gathered}
\operatorname{Logit}\left[\mathrm{p}\left(\mathrm{EM}_{\mathrm{i}}=\mathrm{k}\right)\right]=\ln \left[\mathrm{p}\left(\mathrm{EM}_{\mathrm{i}}=\mathrm{k}\right) / 1-\right. \\
\left.\mathrm{p}\left(\mathrm{EM}_{\mathrm{i}}=\mathrm{k}\right)\right]=\alpha+\beta_{1} \times \mathrm{CEP} 1_{\mathrm{i}}+\beta_{2} \times \mathrm{CEP} 2_{\mathrm{i}}+\beta_{3} \times \mathrm{CEP} 3_{\mathrm{i}}+\beta_{4} \text { Control }
\end{gathered}
$$

In the model, we take the enterprises with "failing" CEP as the reference, so $\mathrm{CEP}_{0}$ is not included in the model test. If $\beta_{1}$ is greater than zero, it means that the enterprise environmental performance has a positive impact on the export mode, if $\beta_{3}>\beta_{2}>\beta_{1}$ indicates that enterprises with higher CEP are always more inclined to export directly than those with lower CEP.

\subsection{Data Collection}

This paper takes the import and export enterprises in Maoming City as samples, collects data from 327 enterprises by means of questionnaire survey and telephone interview, of which 13 enterprises have incomplete data, and the remaining 304 enterprises participate in data analysis. 
International Journal of Innovation, Creativity and Change. www.ijicc.net

Volume 15, Issue 6, 2021

According to the situation of enterprises, the export mode is divided into direct export and indirect export. We also collected information related to enterprise environmental performance and used analytic hierarchy process (AHP) to calculate enterprise environmental performance score.

\section{RESULTS OF THE FINDINGS}

\subsection{Descriptive Statistics}

From the enterprises' survey, of 304 enterprises surveyed, direct export account for $45.72 \%$ (139 companies) and indirect export account for 54.28\% (165 companies). Among these 304 enterprises, only 5 enterprises scored more than 80 in CEP, accounting for only $1.64 \%$. 109 enterprises (accounting for 35.86\%) scored between 70 and 80. In comparison, 183 enterprises (accounting for $60.19 \%$ of all enterprises) scored between 60 and 70, indicating that the CEP of most enterprises in Maoming City has reached the pass level, but is not yet good. The minimum value of CEP score of enterprises is 55.42 points, and the maximum value is 85.63 points. There is a big difference between the maximum and minimum value, indicating that enterprises have a big difference in CEP. 
International Journal of Innovation, Creativity and Change. www.ijicc.net

Volume 15, Issue 6, 2021




International Journal of Innovation, Creativity and Change. www.ijicc.net

Volume 15, Issue 6, 2021

\begin{tabular}{|c|c|c|c|}
\hline \multirow[t]{4}{*}{$\begin{array}{l}\text { Environmental } \\
\text { innovation benefit } \mathrm{A}_{3}\end{array}$} & $\begin{array}{l}\text { Operation rate of environmental } \\
\text { protection equipment } b_{10}\end{array}$ & $\begin{array}{l}\text { Ratio of environmental protection } \\
\text { equipment running time to production } \\
\text { starting time }\end{array}$ & 0.0312 \\
\hline & $\begin{array}{l}\text { Comprehensive utilisation rate of } \\
\text { "three wastes" } b_{11}\end{array}$ & $\begin{array}{l}\text { Ratio of utilisation ratio of "three wastes" } \\
\text { to emissions }\end{array}$ & 0.0237 \\
\hline & $\begin{array}{l}\text { Comprehensive energy } \\
\text { consumption per ten thousand } \\
\text { yuan of output value } b_{12}\end{array}$ & $\begin{array}{l}\text { The energy consumption of ten thousand } \\
\text { yuan of output value is converted into } \\
\text { standard coal }\end{array}$ & 0.1051 \\
\hline & $\begin{array}{l}\text { Emission of "three wastes" per } \\
\text { ten thousand yuan of output } \\
\text { value } b_{13}\end{array}$ & $\begin{array}{l}\text { Total discharge of wastewater, waste gas } \\
\text { and solid waste of ten thousand yuan of } \\
\text { output value }\end{array}$ & 0.0640 \\
\hline
\end{tabular}

Table2 Descriptive Statistics

\begin{tabular}{cccccc}
\hline Variables & $\begin{array}{c}\text { Sample } \\
\text { size }\end{array}$ & Minimum & Maximum & Mean & $\begin{array}{c}\text { Standard } \\
\text { Deviation }\end{array}$ \\
\hline CEP & 304 & 55.42 & 85.63 & 68.9786 & 4.35120 \\
Export Model & 304 & 0.00 & 1.00 & 0.4671 & 0.49974 \\
\hline
\end{tabular}

\subsection{Model Regression Results}

According to Equation 2, when the CEP score of an enterprise is used as its proxy variable, the independent variable is a continuous variable. The results of testing the influence of the CEP on the export mode are shown in line 2 of Table 3. The B value and constant term value in column 1 are linear, which is convenient for us to test the significance. However, compared with linear regression, the coefficient of binary logistic is smaller. According to the binary Logit model, then

$$
\operatorname{Logit}\left[\mathrm{p}\left(\mathrm{EM}_{\mathrm{i}}=\mathrm{k}\right)\right]=-8.305+0.118 \times \mathrm{CEP}_{\mathrm{i}}
$$

The results show that enterprises with better CEP are more inclined to choose direct export mode, and $\mathrm{P}$ value less than 0.05 indicates that the result is significant. Columns 3 to 6 reflect the test result of Equation 3, which is expressed linearly as:

$$
\operatorname{Logit}\left[\mathrm{p}\left(\mathrm{EM}_{\mathrm{i}}=\mathrm{k}\right)\right]=-1.792+1.404 \times \mathrm{CEP} 1_{\mathrm{i}}+2.103 \times \mathrm{CEP} 2_{\mathrm{i}}+3.178 \times \mathrm{CEP} 3_{\mathrm{i}}
$$


International Journal of Innovation, Creativity and Change. www.ijicc.net

Volume 15, Issue 6, 2021

The above result has the same meaning as the result of Equation (4).

\begin{tabular}{lllll}
\multicolumn{1}{r}{ Table3 } & \multicolumn{2}{r}{ Binary Logistic Regression Results } \\
\hline & B & $\operatorname{Exp}(\mathrm{B})$ & \multicolumn{2}{c}{ 95\%,C.I.for $\operatorname{Exp}(\mathrm{B})$} \\
& & & Lower & Upper \\
\hline CEP & 0.118 & 1.126 & ------ & ---- \\
Constant & -8.305 & ------- & & 34.535 \\
CEP (1) & 1.404 & 4.073 & 0.480 & \\
& & & & \\
CEP (2) & 2.106 & 8.217 & 0.956 & 70.606 \\
CEP (3) & 3.178 & 24.000 & 1.140 & 505.193 \\
Constant & -1.792 & ------ & ----- & ------- \\
\hline
\end{tabular}

However, in logistic regression, the coefficient in column $\operatorname{Exp}(B)$ is easier to explain. It reflects the change rate of Odds' occurrence ratio caused by the change of the independent variable by 1 unit. In the second line of Table 3, $\operatorname{Exp}(\mathrm{B})$ is 1.126 , which indicates that when CEP changes by 1 unit, the Odds ratio will change by 1.126 unit, indicating that the higher the CEP is, the more inclined it is to export directly. This feature is even more evident when we use grouping variables for CEP. For example, see lines 4 through 5 in Table 3.CEP1 is CEPO as a reference object, the CEP Exp of (1) (B) a value of 4.073, says in the case of other conditions remaining unchanged, the occurrence ratio of direct export of enterprises with a CEP score of 60 to 70 is 4.073 times that of enterprises with a CEP score of less than 60 . The $\operatorname{Exp}(\mathrm{B})$ value of CEP2 is 8.217, indicating that the occurrence ratio of direct export of enterprises with a CEP score of more than 70 and less than 80 is 8.217 times that of enterprises with a CEP score of less than 60.So, at a $\mathrm{P}$ value of 5\%, $24>; 8.217 \& \mathrm{gt} ; 4.073$ indicates that compared with enterprises with "failing" environmental performance, enterprises with "passing", "good" and "excellent" environmental performance have an increasing tendency to choose the direct export mode. CEP enterprises with "excellent" environmental performance have the strongest tendency to choose direct exports, which is higher than other enterprises. Hypothesis 1 is true.

\section{THE RESEARCH CONCLUSION AND POLICY MEANING}

Enterprise environmental resources are one of the main heterogeneous resources of enterprises. Environmental resources can improve CEP and influence enterprise productivity through 
management innovation and technology innovation, which is the enterprises' innovation value. According to the heterogeneity firm trade theory, firm productivity affects export mode choice, so foreign trade enterprises should choose the appropriate export mode according to their own CEP status to maximise the value of the enterprise. This paper analyses the relationship between CEP and export mode selection from micro-enterprises, takes foreign trade enterprises in Maoming City as the object, and constructs the CEP evaluation system by the analytic hierarchy process (AHP), and carries out the empirical test according to the score results of the evaluation system as the proxy variable of CEP. It is found that the higher the CEP of foreign trade in Maoming, the more inclined it is to choose the direct export mode, and the lower the CEP, the more inclined it is to choose the indirect export mode.

The conclusions of this paper has important implications for the government to formulate relevant policies. The higher the CEP, the more conducive it is to the transition from indirect export to direct export mode, so we should actively start from environmental technology and management innovation to improve environmental benefits to improve the overall CEP.

In April 2014, known as "the history of the most severe environmental law" of new environmental laws, a substantial increase in pollution enterprise's responsibility and penalties were introduced. The Environmental Protection Tax Law, which was formally implemented in 2018 , is China's first tax law that specifically embodies the "green tax system" and vigorously promotes the construction of ecological civilization. The introduction of these two laws has further increased the environmental risks faced by enterprises and made it more costly for enterprises to violate environmental laws. This requires enterprises to strengthen environmental protection and environmental management strategy should be brought into the enterprise development strategy. Promoting an enterprise's environmental performance can achieve green development in an all-round way. On the other hand, the government departments in accordance with the law to strengthen the management of environment at the same time, also want to practice to improve the CEP, such as the preferential tax policy and the financial markets "green" loan ratio. In this way, enterprises can achieve higher CEP through the guidance and incentive of environmental policies , to better cope with the foreign green barriers, expand enterprise direct exports and get a high value return.

Foundation items: This paper is the periodical research results of Guangdong Philosophy and Social Science Program (GD15XGL25, GD20SQ20) and Maoming Science and Technology Program (2019018026). 
International Journal of Innovation, Creativity and Change. www.ijicc.net

Volume 15, Issue 6, 2021

\section{REFERENCES}

Ahn ,J., Khandelwal, A.K. \& Wei, S.J. (2013). The Role of intermediaries in facilitating trade. Journal of International Econnomics,84(4):73-85.

Al-Tuwaijri, S.A., T.E. Christensen, and K.E. Hughes II. (2004). The relations among environmental disclosure, environmental performance, and economic performance: A simultaneous equations approach. Accounting, Organizations and Society, 29:447-471

Chen, D.X (2019). Research on enterprise, differentiation innovation strategy and export mode choice. Journal of Commercial Economics, 11:110-113.

Cheng, Q.L \& Tian, Y.Z. (2012). The effect of business globalization on environmental performance of Chinese manufacturing companies. China Population, Resources and Environment, 22(06):17-22.

Chun,X. \& Chun,W.D. (2013). The influence of corporate control and executive incentive on corporate environmental performance - Based on evidence from listed companies in the Chemical industry. Journal of Southwest Minzu University (Humanities and Social Science 34(6),160-164.

Feng, Q. G. (2016). Supply side reform and management accounting innovation. Friends of Accounting 7:128-133.

Hang, M., Geyer-Klingeberg, J., \& Rathgeber, A. W. (2018). It is merely a matter of time: A meta-analysis of the causality between environmental performance and financial performance. Business Strategy and the Environment.201,(07): 1-17.

Hang, M., Geyer-Klingeberg, J., Rathgeber, A., \& Stöckl, S. (2017). Economic development matters: A meta-regression analysis on the relation between environmental management and financial performance. Journal of Industrial Ecology, 22(4), 720-744.

Hoang, T. C., Abeysekera, I., \& Ma, S. (2016). Board diversity and corporate social disclosure: evidence from Vietnam. Journal of Business Ethics, 151(3), 833-852.

$\mathrm{Hu}, \mathrm{Q}$. Y. (2012). Research on relationship between environmental performance and financial performance of Chinese listed companies [J]. China Population, Resources and Environment, 22(6):3-10.

Hughes, S. B., A. Anderson, and S. Golden. (2001). Corporate environmental disclosures: are they useful in determining environmental performance? Journal of Accounting and Public Policy, 20:217-240

Hussain, N., Rigoni, U., \& Cavezzali, E. (2018). Does it pay to be sustainable? Looking inside the black box of the relationship between sustainability performance and financial performance. Corporate Social Responsibility and Environmental Management.,4: 1-14.

International Organization for Standardization [ISO] (2004). ISO 14004:2004. Environmental management systems: General guidelines on principles, systems and supporting techniques. Geneva: ISO.

Jin, Z. H. (2019). Heterogeneous enterprises' export trade model selection: Based on the 
International Journal of Innovation, Creativity and Change. www.ijicc.net

Volume 15, Issue 6, 2021

inference of policy uncertainty fluctuation. Social Sciences of Beijing,11:15-24.

Li, C. D. (2015). A study on "export-productivity paradox" of Chinese firm. The Journal of World Economy,5:148-175.

Li, G., \& Liu, P. (2015). Impact of the upgrade of Iron and Steel environmental regulation standard on enterprise behaviour and environmental performance. China Population, Resources and Environment 25 (12):8-14.

Li, L. (2013). Comprehensive evaluation of enterprise environmental performance based on AHP-Fuzzy model. Friends of Accounting 4:14-19.

Li, S. \& Qiu, G. Y. (2013). Steel \& Iron enterprises environmental performance evaluation: Based on DEA model. Ecological Economy,2632):113-118.

Li, X. (2017). Political connections, financial subsidies and corporate environmental performance. Communication of Finance and Accounting 18:40-44.

Liao, X. F., \& Yan, W. S. (2015). A empirical study of relationship between corporate governance and environmental performance. Communication of Finance and Accounting.18:40-43.

Liu, H. Y. (2017). The relationship between enterprises' environmental performance and green credit - Data sample analysis based on the mining service, papermaking and electricity industry. Studies on Socialism with Chinese Characteristics,3: 85-92.

Liu, H. Y., Gao, L., \& Lin, L. T. (2019). Internet and the transformation of export mode. China Economic Quarterly,19(1):261-280.

Lyu, J. (2012). An empirical study on the relations between environmental disclosure and environmental performance. Chinese Journal of Management,9 (12) :1856-1863.

Ma, L. M. (2014). Enterprise scale heterogeneity and export mode choice: Indirect, mixed and direct export. Contemporary Finance \& Economics,9:98-109.

Ma, L. M., \& Zhang. Q. Q. (2016). Firm productivity and export mode choice: Non-export, indirect and direct export. International Economics and Trade Research, 32(6):33-47.

Ma, Y. L. (2014). Environmental investment efficiency and enterprise financing Ability. Audit Monthly,8: 21-23.

Pang, H. P., \& Rao. X. Q. (2019). Environmental protection law, institutional environment and corporate environmental performance. Journal of Shanxi University of Finance and Economics,41(03):71-86.

Qiu, Y. Z., \& Zhang, X. X. (2018). Female executives and corporate environmental performance - An empirical study based on the listed companies in Chinese. Finance Research,21(03):32-43.

Shang. H. T., \& Zhu, L. R. (2018). The relationship among environmental R\&D subsidies environmental R \& D investments and corporate environmental performance. Soft Science,32(05):40-44.

Tang, G. P., \& Wang. R. X. (2019). Has 'the spirit of craftsman' improved enterprise environmental performance. Journal of Shanxi University of Finance and Economics, 41(5):81-93. 
International Journal of Innovation, Creativity and Change. www.ijicc.net

Volume 15, Issue 6, 2021

Tang, P. H. (2019). The impact of institutional investors on corporate environmental performance. China Circulation Economy,13: 54-56.

Tian, X. Y. (2011). Application of fuzzy analytic hierarchy process in environmental performance evaluation. Pioneering with Science \& Technology Monthly,1:112$113+116$.

Walls, J. L., Berrone, P., \& Phan, P. H. (2012). Corporate governance and environmental performance: is there really a link? Strategic Management Journal, 33(8), 885-913.

Wang, P. \& Zhao, Y. P. (2012). An empirical study of the corporate environmental performance and financial performance 'Win-win Correlation. Communication of Finance and Accounting, 12:50-52.

Xie, D. M. (2012). On the enterprise environment performance management research in China based on the concept of eco-efficiency. Public Finance Research, (11):28 31

Yang, D. Y., \& Xie, Y. (2019). Social responsibility, green innovation ability and enterprise environmental performance. Communication of Finance and Accounting.6:100-104

Yang, J. Y. (2019). An empirical analysis of the influencing factors of enterprise environmental performance - A case study of listed manufacturing companies. Hebei Enterprise,5:9192.

Yang, J. Y., \& Xu, M. (2015). Financing diversity and the choice of sustainable export mode of Chinese enterprises. The Journal of World Economy,4:50-76.

Yao, C. H. (2015). Enterprise environmental performance evaluation based on EBM - A case study of enterprises in West Guangdong province. Friends of Accounting,19:42-46.

Ye, C. G., Wang, Z., Wu, J. F., \& Li, H. (2015). External governance, environmental information disclosure and the cost of equity financing. Nankai Business Review, 18 (05) :85-96.

Ye, C. G., Wang. Z., \& Wu. J. F. (2016). Corporate governance, political connection and environmental performance. Contemporary Economic Management,38(02):19-25.

Zhou, S. H., Wu, C. L., \& Liu. G. Q. (2015). Enterprise eco-Efficiency, financing constraints heterogeneity and export modes selection - Based on the Chinese enterprises survey data of the World Bank in 2013. Finance \& Trade Economics, 10:134-147.

Zhu, Z. W. (2015). A study on environmental performance of China's listed company in the electric power industry (2011-2013). Journal of Industrial Technological Economics, 10:83-90. 